\title{
KONFLIK SOSIAL MENANTU YANG TINGGAL SERUMAH DENGAN MERTUA (STUDI KASUS DI DESA LEMPANG KECAMATAN TANETE RIAJA KABUPATEN BARRU)
}

\author{
Milda Rahmah $^{1}$, Hidayah Quraisy ${ }^{2}$, Risfaisal $^{3}$ \\ ${ }^{1}$ Pendidikan Sosiologi, Universitas Muhammadiyah Makassar \\ Email: mildarahmah@gmail.ac.id \\ ${ }^{2}$ Pendidikan Sosiologi, Universitas Muhammadiyah Makassar \\ Email: hidayahquraisy@unismuh.ac.id \\ ${ }^{3}$ Pendidikan Sosiologi, Universitas Muhammadiyah Makassar \\ Email: risfaisal@unismuh.ac.id
}

\begin{abstract}
The purpose of this study is to find out what causes conflict with in-laws who live at home with inlaws and how to form conflict resolution strategies for in-laws who live at home with in-laws. The research conducted is qualitative research. The research sample uses purposive sampling with 5 informants. Data collection techniques used by researchers are observation, interviews and documentation. Data analysis method used is descriptive method. The results of the study prove that based on observations of these phenomena it can be seen that in-laws who live in the same house with in-laws do not feel well-being in their lives. Welfare does not just emerge from within the individual, so the individual must learn and get used to achieving that well-being. Most individual problems are driven by feelings of discomfort and cannot control their emotions so that they affect their well-being.
\end{abstract}

Keywords: Social conflict, Son-in-law and In-laws

\begin{abstract}
Abstrak. Tujuan penelitian ini adalah untuk mengetahui apa penyebab konflik terhadap menantu yang tinggal serumah dengan mertua dan bagaimana bentuk strategi penyelesaian konflik terhadap menantu yang tinggal serumah dengan mertua. Penelitian yang dilakukan merupakan penelitian kualitatif. Sampel penelitian mengunakan purposive sampling dengan 5 informan. Teknik pengumpulan data yang lakukan oleh peneliti adalah Observasi, wawancara dan dokumentasi. Metode analisis data yang di gunakan yaitu metode deskriptif. Hasil penelitian membuktikan bahwa Berdasarkan pengamatan terhadap fenomena tersebut dapat dilihat bahwa menantu yang tinggal serumah dengan mertua tidak merasakan kesejahteraan dalam hidupnya. Kesejahteraan tidak muncul begitu saja dari dalam diri individu, sehingga individu harus belajar dan membiasakan diri untuk mencapai kesejahteraan itu. Kebanyakan permasalahan individu dipacu dengan perasaan yang kurang nyaman dan tidak dapat mengendalikan emosinya sehingga akan mempengaruhi kesejahteraannya.
\end{abstract}

Kata Kunci : Konflik Sosial, Menantu dan Mertua

\section{PENDAHULUAN}

Manusia diciptakan Tuhan Yang Maha Esa untuk saling mencintai dan hidup berpasangpasangan. Semua orang butuh cinta, baik mencintai maupun untuk dicintai. Cinta tidak memandang usia, jenis kelamin dan status sosial. Jatuh cinta kepada lawan jenis adalah suatu hal yang alamiah, hal ini terjadi ketika orang mulai menginjak usia dewasa. Karena salah satu tugas perkembangan 
orang dewasa adalah membina keluarga, sehingga mempunyai pasangan hidup menjadi penting yang kemudian diwujudkan dengan cara menikah. Pernikahan merupakan perjanjian, karena dari padanya lahir hak-hak dan kewajiban dari dan kepada setiap orang yang terkait didalamnya (suami, istri, anak yang lahir daripadanya).

Keluarga adalah tempat berlindung yang sangat aman dan nyaman bagi setiap orang, karena didalam keluargalah seseorang yang ada didalamnya termasuk suami, istri, dan anak seharusnya mendapatkan kesenangan, ketenangan, dan kasih sayang yang penuh. Sehingga dapatlah terwujud suatu peribahasa bahwa "Rumahku adalah Surgaku". Yang pasti apabila rumah itu adalah surga, siapapun yang ada didalamnya pasti akan merasa betah karena tidak ada yang merasakan kesepian, kesendirian, ataupun kekurangan kasih sayang.

Namun munculnya konflik atau permasalahan bisa saja terjadi apabila di dalam satu atap atau di dalam satu rumah terdapat lebih dari satu kepala keluarga. Di Desa Lempang Kecamatan Tanete Riaja ini hubungan antara anak menantu dan ibu mertua yang tinggal dalam satu rumah seringkali dianggap tidak akur. Maka dari itu penulis tertarik untuk mengambil tema ini agar bisa dicari akar permasalahan tentang apa yang menyebabkan dan bagaimana strategi penyelesaian konflik antar menantu yang tinggal serumah dengan mertua. Bisa dibayangkan bahwa seorang mertua adalah sosok yang baru saja dikenal oleh seorang menantu. Bagaimana dan seperti apa cara untuk mencari perhatian seorang mertua adalah merupakan tugas tersendiri bagi seorang menantu yang harus bisa dipelajari dan dihadapi.

Konflik kadang bisa dipicu oleh hadirnya orang ketiga di dalam suatu rumah tangga. Kehadiran mertua atau apabila pasangan yang masih ikut dengan mertua dalam tempo satu atau dua bulan mungkin masih dalam tahapan aman-aman saja. Tetapi apabila sampai bertahun-tahun seorang kepala keluarga tidak bisa mandiri untuk membawa anak dan istrinya keluar membangun tempat tinggal sendiri pasti akan menimbulkan efek yang buruk. Efek yang paling kecil adalah ketidak mandirian keluarga yang menumpang (menantu) kepada keluarga yang lain.

Peneliti memilih topik ini karena peneliti ingin mengetahui apa saja, sebab dan strategi penyelesaian konflik antara menantu perempuan dan ibu mertua yang tinggal dalam satu rumah. Pada penelitian ini, peneliti mengambil pasangan menantu perempuan dengan ibu mertua yang kurang lebih tinggal satu rumah dalam kurun waktu lebih satu tahun. Penelitian ini dilakukan di Desa Lempang Kecamatan Tanete Riaja Kabupaten Barru. Berdasarkan fenomena dan penelitian yang dialami mengenai banyaknya konflik yang terjadi didalam perkawinan atau berkeluarga tidak hanya terjadi pada pasangan suami istri, namun konflik di dalam keluarga dapat terjadi antara hubungan menantu dan ibu mertua.

\section{METODE PENELITIAN}

Jenis penelitian ini adalah kualitatif dengan metode analisis deskriptif yang bertujuan untuk mengetahuan penyebab terjadinya dan strategi penyelesaian konflik menantu yang tinggal serumah dengan mertua. Sampel penelitian mengunakan purposive sampling dengan 5 informan. Teknik pengumpulan data yang lakukan oleh peneliti adalah Observasi, wawancara dan dokumentasi. Kemudian dianalisis melalui reduksi data (data reduction), penyajian data (display data), penarikan kesimpulan (conclusion) dan menggunakan teknik keabsahan data.

\section{HASIL DAN PEMBAHASAN}

Sesuai dengan hasil penelitian yang menjelaskan tentang bagaimana faktor penyebab konflik menantu yang tinggal serumah dengan mertua, olehnya itu peneliti menginterpretasi di dalam pembahasan ini. Konflik yang terjadi antara mertua dan menantu memang selalu menjadi topik yang menarik untuk didiskusikan karena tidak sedikit orang yang memiliki masalah dalam berhubungan dengan mertua atau menantunya. Tidak hanya menantu perempuan dan ibu mertua saja yang bisa terlibat dalam konflik, menantu laki-laki pun juga bisa terjebak dalam masalah ini.

Peneliti melakukan penelitian secara kualitatif deskriptif menggambarkan hal apa saja yang terjadi di Desa Lempang Kecamatan Tanete Riaja Kabupaten Barru melakukan pengkajian penyebab terjadinya konflik menantu yang tinggal serumah dengan mertua. 


\section{a. Mertua Sering Berkomentar}

Penyebab terjadinya konflik menantu dan mertua di Desa Lempang Kecamatan Tanete Riaja Kabupaten Barru disebabkan karena mertua sering berkomentar kepada menantu. Misalnya tentang cara mengurus anak ataupun soal makanan. Sikap menantu yang seperti itu akan membuat menantu tidak nyaman dan serba salah. Keadaan akan bila hubungan antara menantu dan mertua sangat baik. Apalagi kalau mertua menganggap sang menantu bak anak sendiri. Ada yang mengatakan kalau pria lebih mudah beradaptasi bila tinggal bersama dengan orang tua istri daripada istri yang tinggal serumah dengan orang tua suami. Namun menurut penulis, akurnya hubungan mertua menantu dalam satu rumah sangat dipengaruhi karakter keduanya.

\section{b. Mertua Sering Ikut Campur}

Berbagai macam karakteristik atau kepribadian yang dimiliki orang tua dalam menyikapi suatu problem atau masalah yang terjadi pada menantu dan mertua khususnya yang berada di Desa Lempang Kecamatan Tanete Riaja Kabupaten Barru. Peneliti terkadang melihat orang tua masih ikut campur atau mengurusi masalah pribadi antara suami dan istri (menantu), karena orang tua masih merasa punya hak dalam memberikan perhatian terhadap anaknya.

Salah satu contoh kasus yang sering terjadi di Desa Lempang Kecamatan Tanete Riaja Kabupaten Barru yaitu ketika terjadi pertengkaran (konflik) antara pasangan suami istri yang sebenarnya masih bisa terselesaikan oleh pihak tersebut tetapi orang tua masih sering turut ikut campur dalam menangani kasus permasalahan tersebut.

\section{c. Mertua yang Kerap Membandingkan Menantu}

Hasil pengamatan peneliti melihat terkadang mertua yang kerap membandingkan menantu yang satu dengan menantu yang lain. Hal tersebut sesuai dengan fitrah manusia yang tidak bisa dipungkiri kerap kali melihat dari sisi pencapaian profesi, gelar, jabatan, dan kekuasaan yang dimiliki. Berdasarkan fakta sosial yang terlihat di Desa Lempang Kecamatan Tanete Riaja Kabupaten Barru hasil informan yang saya dapatkan bahwa mertua sering kali membandingkan menantu dari sisi pendapatan ekonomi yang didapatkan tidak sesuai dengan kebutuhan hidup yang ingin dicapai.

Di tengah era modernisasi dan globalisasi, masyarakat yang serba tuntutan untuk mendapatkan ekonomi berlomba-lomba mendapatkan profesi atau pekerjaan yang layak terpandang di masyarakat. Hal ini membuat kepada para mertua untuk membanding-bandingkan para menantu dengan orang lain dari sisi pendapatan ekonominya. Dalam hal aspek tersebut, secara naluriah bagi para mertua mengalami kecemburuan sosial di dalam membangun kehidupan keluarga atau rumah tamgga. Kecemburuan sosial tersebut akan mengalami konflik manifest (tersembunyi) bagi para mertua terhadap menantu di dalam suatu keluarga tersebut khususnya di Desa Lempang Kecamatan Tanete Riaja Kabupaten Barru.

\section{d. Menikah Tanpa Restu Orang Tua}

Berdasarkan hasil pengamatan yang terjadi di Desa Lempang Kecamatan Tanete Riaja Kabupaten Barru bahwa para anak dari orang tua mereka melakukan pernikahan tanpa sepenuhnya mendapatkan restu orang tua, dikarenakan adanya perbedaan status sosial antara pihak laki-laki dan pihak perempuan. Masyarakat yang ada di Desa Lempang Kecamatan Tanete Riaja Kabupaten Barru memandang bahwa proses pernikahan sebagai ajang untuk mencapai prestise sosial yang terpandang baik di masyarakat. Ketika melakukan proses penikahan mendapatkan restu orang tua sangat amatlah penting karena untuk mendapatkan keberkahan di dalamnya.

Strategi penyelesaian konflik yang terjadi di Desa Lempang Kecamatan Tanete Riaja Kabupaten Barru, berbagai macam hal yang dilakukan oleh informan untuk menyelesaikan konflik berdasarkan hasil wawancara yang diperoleh. Banyak menantu yang tinggal betah tinggal dirumah mertua 
dikarenakan tutuntuan mertua yang terlalu tinggi sehingga menantu tidak bisa tahan dengan tahan itu. Konflik adalah suatu masalah sosial yang timbul karena adanya perbedaan pandangan yang terjadi di dalam masyarakat. Konflik antara menantu dan mertua merupakan salah satu masalah yang paling sering muncul dalam kehidupan rumah tangga, apalagi jika keduanya masih tinggal dalam satu rumah. Saat terjadi permasalahan walaupun itu kecil dan sepele, namun bisa saja membesar dan melebar pada masalah lain. Sehingga hubungan kekeluargaan jadi berantakan.

Di keluarga tak pernah lepas dari konflik. Baik itu antar anggota keluarga sendiri atau antar antar individu di luar keluarga. Sebenarnya sumber dari konflik adalah komunikasi yang tak lancar, efektif, salah persepsi dan salah paham dari masing-masing individu. Selama dalam hidup, manusia selalu hidup dalam konflik. Awal mulanya konflik dengan dirinya sendiri, lalu dengan orang lain.Tetapi sebagai bagian dari keluarga, tentu kita tak bisa melawan atau mengelak dari apa yang namanya konlfik. Konflik itu alami karena manusia itu saling berbeda watak, karakter, kepribadiannya. Seperti masalah yang dialami oleh menantu yang masih tinggal serumah sengan mertuanya di Desa Lempang Kecamatan Tanete Riaja Kabupaten Barru.

Hubungan mertua dengan menantu kerap diwarnai ketidakharmonisan. Hal itulah yang akhirnya membuat banyak orang yang tidak ingin tinggal satu rumah dengan mertua atau menantunya. Begitu banyak penolakan yang diucapkan para menantu ketika dilontarkan ide untuk tinggal serumah dengan mertua. Sejak dulu kala sampai saat ini, hubungan antara menantu dan mertua memang sering digambarkan tidak harmonis dan rentan masalah. Terutama antara mertua perempuan dengan menantu perempuan. Karena itulah, jika ada pilihan, banyak orang yang lebih memilih tinggal terpisah dari mertuanya.

Jadi hasil dari penelitian ini tentang strategi penyelesaian konflik terhadap menantu yang tinggal serumah dengan mertua yaitu seorang menantu yang tinggal serumah dengan mertua yaitu meskipun menantu tidak cocok dengan mertua, tapi menantu tidak perlu mengumbarnya. Cukup simpan dalam hati dan cukup menantu saja yang tahu. Bagaimanapun juga sekarang dia adalah salah satu orangtua yang harus dihormati.

\section{KESIMPULAN}

1. Penyebab terjadinya konflik menantu yang tinggal serumah dengan mertua biasanya disebabkan oleh beberapa faktor yaitu mertua sering berkomentar, mertua sering ikut campur, mertua yang kerap membandingkan menantu dan menikah tanpa restu orang tua. Konflik yang terjadi antara mertua dan menantu memang selalu menjadi topik yang menarik untuk didiskusikan karena tidak sedikit orang yang memiliki masalah dalam berhubungan dengan mertua atau menantunya. Tidak hanya menantu perempuan dan ibu mertua saja yang bisa terlibat dalam konflik, menantu laki-laki pun juga bisa terjebak dalam masalah ini.

2. Strategi penyelesaian konflik antara menantu yang tinggal serumah dengan mertua yaitu perkataan mertua tidak dimasukkan ke dalam hati, menjalin komunikasi yang baik, banyak minta saran kepada mertua dan jangan menghindar. Konflik terhadap menantu yang tinggal serumah dengan mertua yaitu seorang menantu yang tinggal serumah dengan mertua meskipun menantu tidak cocok dengan mertua, tapi menantu tidak perlu mengumbarnya. Cukup simpan dalam hati dan cukup menantu saja yang tahu. Bagaimanapun juga sekarang dia adalah salah satu orangtua yang harus dihormati. 


\section{DAFTAR PUSTAKA}

Devi, Angga Herlin. 2017. Pengembangan Objek dan Daya Tarik Wisata Alam Sebagai Daerah Tujuan Wisata Di Kabupaten Karanganyar. Jurnal Sosiologi DILEMA. 32(1):34-44.

Marliastri,S. 2015. Dampak Sosial Ekonomi Masyarakat Terhadap Obyek Wisata Maros Water Park Pattunuang Isue Kabupaten Maros. Makassar: Skripsi Fakultas Keguruan dan Ilmu Pendidikan Universitas Muhammadiyah Makassar.

Nursalam. 2016.Teori Sosiologi Klasik, Modern, Postmodern, Saintifik, Hermaneutik. Yogyakarta. Penerbit Writig Revolution.

Riswandi. 2015. Dampak Sosial Wisata Pantai Galesong Kabupaten Takalar. Makassar: Skripsi Fakultas Keguruan dan Ilmu pendidikan Universitas Muhammadiyah Makassar.

Risfaisal. 2013. Perubahan Sosial Budaya Pada Masyarakat Adat Ammaoa Kajang. Makassar: Tesis Pasca Sarjana Universitas Negeri Makassar.

Bagus, Denny.2009. dampak pengembangan obyek wisata. http://jurnalsdm.blogspot.com/2009/08/dampak-pengembangan-obyek-wisata.dampak.html\#. (online) di akses pada tanggal 1 Januari 2019

Dammar, Swarni.2018. eksotisme wisata alam dante pine. http://www.google.co.id/amp/s/makassar.sindonews.com/newsread/8238/7/eksotismewisata-alam-dante-pine-enrekang-nan-memukau-1524290654. (online). Diakses tanggal 15 Januari 2019.

Havis Amran's. 2015. Pengertian sumber daya Alam. https://apitswar.wordpress.com//pengertiansumber-daya-alam-dan-jenisnya/. (online) Diakses tanggal 5 Januari 2019.

Madebayu. 2009. Dampak sosial pengembangan wisata. http://10/dampak-sosial-pengembanganpariwisata-terhadap-masyarakat-dikawasan-tanjungbenoa. (online) diakses pada 15 Januari 2019.

Nur Fatih, 2016. seputar pengertian umum. http://seputar-pengertian-umumblogspot.com/2016/0/ pengertian-defenisi-pariwisata.html/m=1 . (online) di akses tangga 13 Februari 2019.

Teropong. 2017. Pengertian sumber daya alam. https://formteropong.id/2017/10/16/pengertiansumber-daya-alam-klasifikasi-jenispengelolaan-pemanfaatan-sumber-daya-alam-danhambatannya/. (online) di akses tanggal 14 Februari 2019.

Parepos. Fajar. 2019. Potensi ekonomi kabupaten enrekang.http://parepos.fajar.co.id/2019/06/melirik-potensi-ekonomikabupatenenrekang/.(online) diakses tanggal 09 Februari 2019. 